The architecture of coopetition: strategic intent, ambidextrous managers, and knowledge sharing

Chandrasekararao Seepana; Antony Paulraj; Fahian Anisul Huq

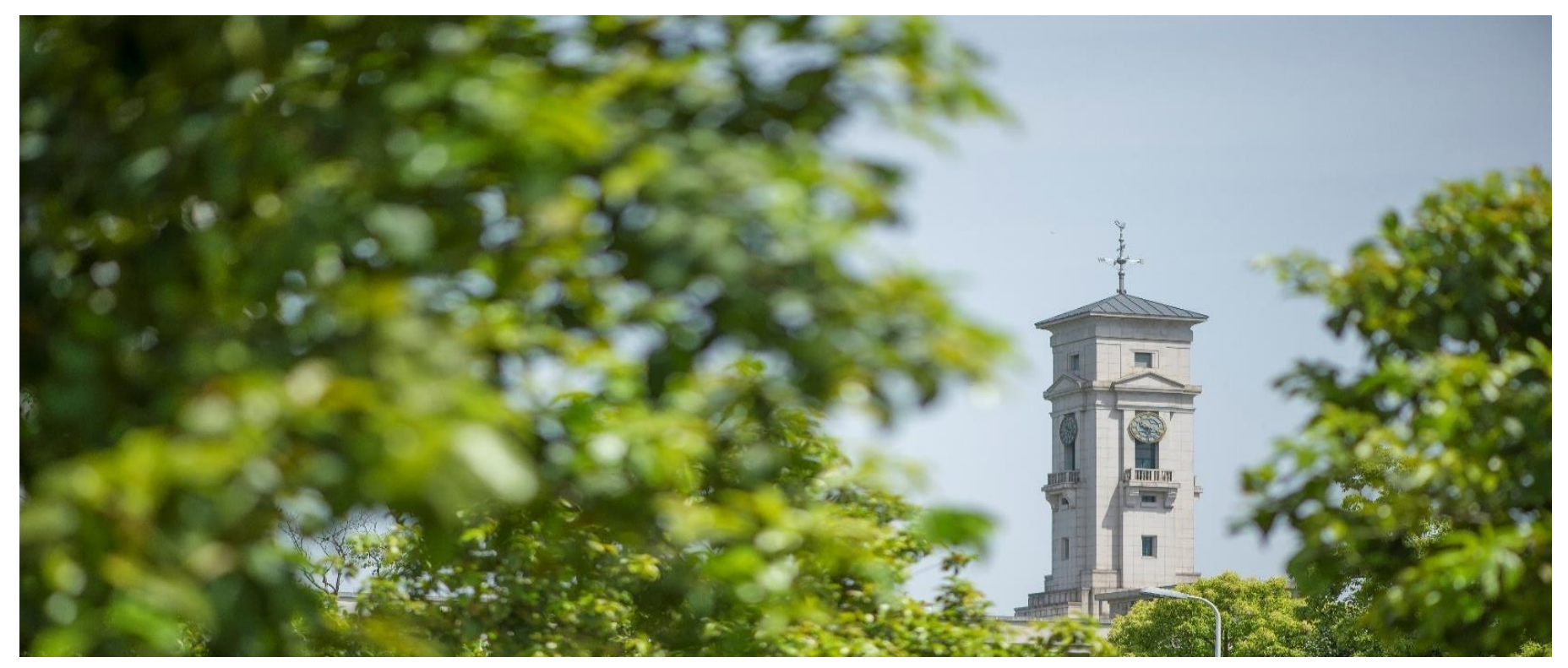


Faculty of Business, University of Nottingham Ningbo China, 199 Taikang East Road, Ningbo, 315100, Zhejiang, China.

First published 2020

This work is made available under the terms of the Creative Commons Attribution 4.0 International License:

http://creativecommons.org/licenses/by/4.0

The work is licenced to the University of Nottingham Ningbo China under the Global University Publication Licence:

https://www.nottingham.edu.cn/en/library/documents/researchsupport/global-university-publications-licence-2.0.pdf 


\title{
The architecture of coopetition: strategic intent, ambidextrous managers, and knowledge sharing
}

\author{
Chandrasekararao Seepana \\ $\mathrm{PhD}$ Candidate \\ Alliance Manchester Business School \\ The University of Manchester \\ Room 3.017 \\ Booth Street West, Manchester M15 6PB \\ Phone: +44 (0) 1612756540 \\ Email: chandrasekararao.seepana@manchester.ac.uk
}

\author{
Antony Paulraj \\ Li Dak Sum Chair Professor in Information Systems and Operations Management \\ Nottingham University Business School China \\ University of Nottingham \\ Room 248 Trent Building \\ 199 Taikang East Road, Ningbo 315100, China \\ Phone: +86 (0) 57488180000 - 8631 \\ Email: antony.paulraj@nottingham.edu.cn
}

Fahian Anisul Huq

Senior Lecturer in Operations and Supply Chain Management

Alliance Manchester Business School

The University of Manchester

Room 3.043

Booth Street West, Manchester M15 6PB

Phone: +44 (0) 1612756484

Email: fahian.huq@manchester.ac.uk 


\section{Introduction}

Coopetition - a phenomenon of simultaneous pursuit of cooperation and competition between firms - is increasingly becoming popular in both academia and practice. The manifestation of the contradictory logics of cooperation and competition within the same relationship makes coopetition a paradoxical relationship (Bengtsson and Kock, 2014, Bengtsson et al., 2016b, Raza-Ullah, 2018, Jakobsen, 2020), wherein the cooperation part that underscores collective interests to create greater value coexists with the competition part that emphasizes private gains from the value created (Khanna et al., 1998, Raza-Ullah et al., 2014, Gnyawali et al., 2016). The juxtaposing of these two equally important yet interrelated contradictory logics into one relationship makes coopetition paradoxical (Luo and Rui, 2009, Bengtsson and Kock, 2014, Jakobsen, 2020). Coopetition primarily occurs between two rival firms; relationships between Sony and Samsung (Ritala and Hurmelinna-Laukkanen, 2009, Gnyawali and Park, 2011), and Google and Apple (Luo, 2007a, Estrada and Dong, 2019) signify how coopetition could materialize.

Among others, an important shared trait of Samsung (Hitt et al., 1995), Sony (Hamel and Prahalad, 2010), and Apple (Mantere and Sillince, 2007) is their ability to maintain a strong strategic intent. Strategic intent represents a firm's long-term position of attaining desired objectives such as growth, market dominance, and maintaining supremacy (Hamel and Prahalad, 1989, Haugstetter and Cahoon, 2010, Mariadoss et al., 2014). Given that external learning, investments, as well as research and development (R\&D) efforts are needed to attain the underlying objectives, strategic intent is likely to drive firms to seek out appropriate alliance partners (Hamel and Prahalad, 1989, Ariño, 2002, Koza and Lewin, 2000, Mariadoss et al., 2014), even though they might be competitors (Luo, 2007a). Engaging in coopetition is a firmspecific decision; therefore, it could be arguably driven by the firm's strategic intent (Dowling et al., 1996, Bonel and Rocco, 2007, Luo, 2007a, Velu, 2016, Gnyawali and Charleton, 2018). Accordingly, strategic intent could be envisioned as a key antecedent to coopetition.

While some scholars suggest the link between strategic intent and coopetition to be straightforward (Luo, 2007a, Velu, 2016, Gnyawali and Charleton, 2018), others contradict the very assumption that strategic intent could drive the formation of different types of relationships (Ryals and Davies, 2013). Alternatively, rather than directly leading to interorganizational engagements, studies also posit that strategic intent might possibly require other intervening mechanisms so as to result in specific inter-organizational engagements (Parmigiani and Rivera-Santos, 2011). Studies argue that the link between strategic intent and relationship formation - in our case, coopetition - can be facilitated by intermediaries such as 
communication channels (Hitt et al., 1995), manager intervention (O'Reilly 111 and Tushman, 2011, Haugstetter and Cahoon, 2010), and other transmitting variables (Koza and Lewin, 1998, Koza and Lewin, 2000). Overall, these contradictions imply an unclear understanding when it comes to the link between strategic intent and coopetition. Therefore, we contend that it is important to uncover this association given the prominence as well as the confusion surrounding strategic intent's role in the pursuit of coopetitive relationships.

A firm's need to engage in coopetition could be attributed to the need to overcome environmental conditions (Gnyawali and Park, 2011, Ritala, 2012, Luo, 2007a, Gnyawali and Charleton, 2018) advancing competitive advantage (Bengtsson and Kock, 2000, Gnyawali and Charleton, 2018, Gast et al., 2019), and to survive competitive business environments (Hoffmann et al., 2018). Coopetition's approach of doing two things - cooperation and competition - simultaneously can be viewed from the lens of ambidexterity (Bengtsson et al., 2016b, Yousef et al., 2020) as ambidexterity is argued to be the fundamental condition to define the paradoxical concept of coopetition (Bengtsson et al., 2016b). However, engaging in paradoxical dualities may not be straightforward for firms; among others, it might require ambidextrous managers (O'Reilly 111 and Tushman, 2011, Mom et al., 2009, Bengtsson et al., 2016b, Felício et al., 2019) who can articulate the intent of doing two opposing things simultaneously. Additionally, in relationships, a firm's strategic intent needs to be aligned with that of its partner so as to ensure congruence between their intents (Spekman et al., 1996, Haugstetter and Cahoon, 2010). Among others, knowledge sharing can assist to reconceive a firm's strategic intent (Madhok and Tallman, 1998, Haugstetter and Cahoon, 2010) so as to align it with that of the partner's intent (Hitt et al., 1995, Sirmon and Lane, 2004, Parmigiani and Rivera-Santos, 2011). The reconceived strategic intent could eventually guide managers to pursue ambidextrous activities and succeed in coopetitive relationships. Additionally, knowledge sharing may also assist firms in learning about the alliance environment (Simonin, 2004), and potentially help firms to comprehend and pursue activities of simultaneous cooperation and competition (Grant and Baden-Fuller, 2004, Bouncken and Kraus, 2013, Gast et al., 2019). Pfeffer and Sutton (2000) reckon the importance of knowledge and managers in reducing the 'knowing-doing' gap in firms, wherein strategic intent could be viewed as knowing and coopetition could be viewed as doing. Although extant literature posits knowledge sharing and ambidextrous managers as potentially significant variables to bridge the link between strategic intent and coopetition, it lacks clarity on the operationalization and empirical validation of their intrinsic association. Moreover, given the confusion surrounding 
the relationship between the strategic intent and coopetition, we believe that it is pertinent to investigate the key role of ambidextrous managers as well as knowledge sharing.

When it comes to knowledge sharing in coopetition settings, we acknowledge that it tends to cause sharing vs protection tensions between partner firms which eventually requires a combination of legal, formal, and informal protection mechanisms to address them (Ritala and Hurmelinna-Laukkanen, 2013, Estrada et al., 2016, Fernandez and Chiambaretto, 2016, Chiambaretto et al., 2019, Gast et al., 2019). However, given our ambition to investigate how a firm's strategic intent is complemented by knowledge sharing between the coopetitive partners, we choose not to get into details of knowledge protection in this research. In summary, the purpose of the study is to not only investigate the relationship between strategic intent and coopetition, but also to explore how the intervening variables of knowledge sharing and manager's ambidexterity could influence this relationship. By testing the hypotheses relating these factors of interest (please refer to Figure 1), our study makes several contributions to extant literature. First, the role of knowledge sharing is largely overlooked in studies that discuss the relationship between strategic intent and manager's capabilities (O'Reilly 111 and Tushman, 2011, O'Shannassy, 2016, Jarzabkowski et al., 2019). It is specifically important to investigate the role of knowledge, since partner firms tend to maintain unique strategic intents which need to be aligned when pursuing relationships. While our results suggest a negative direct effect, it also indicates that strong knowledge sharing routines could positively moderate this effect. It means that unless knowledge sharing is present in coopetition, a firm's strategic intent by itself will not be able to guide its managers. Specifically, our study showcases the importance of knowledge when it comes to the link between strategic intent and ambidextrous managers. We believe that this finding also adds to other contexts of interfirm relationships. Second, while previous studies discuss potential relationships between ambidextrous managers and various paradoxical activities inherent to coopetition (Luo, 2007b, Bengtsson et al., 2016a, Estrada and Dong, 2019, Chiambaretto et al., 2019, Bouncken et al., 2020), they lack clarity in explaining what skillsets could make managers ambidextrous. Additionally, extant research has also overlooked the potential direct relationship between ambidextrous managers and coopetition. In fact, scholars call for (1) clarity on the managerial characteristics in ambidextrous relationships (Felício et al., 2019) and (2) empirical investigation into the nature of managers involved in coopetitive relationships (Czakon et al., 2019). As a response to these calls, our study proposes exploration and exploitation as the ambidextrous skills of managers that are essential to pursue coopetition. Given that we sought responses from top-ranking managers in our data collection efforts, we focus on the ambidextrous skills of such managers. 
Third, as pointed out earlier, our study contributes to extant literature by trying to shed some light on the contradictions surrounding the link between strategic intent and coopetition (Luo, 2007a, Yami et al., 2010, Velu, 2016, Gnyawali and Charleton, 2018). Our finding forwards knowledge sharing and ambidextrous managers as intervening variables, in that when complemented with knowledge sharing, strategic intent could enable managers to pursue coopetition successfully. This finding offers novel insights to potential coopetitors about what triggers coopetition within a firm (i.e., strategic intent) and how successful coopetition could eventually materialize (utilizing necessary knowledge routines and ambidextrous managers).

-- Insert Figure 1 here --

\section{Theoretical background}

\section{Strategic intent}

Strategic intent symbolizes a clear-cut statement of a firm's ambition and desired market leadership position (Hamel and Prahalad, 1989, Johnson and Sohi, 2001) and serves as an effective communication to internal and external stakeholders (O'Shannassy, 2016). The expressions of the strategic intent of several established organizations would offer better impression of how this materialises. For instance, Japanese earth moving equipment maker 'Komatsu' sets out to encircle 'Caterpillar', its American rival. Similarly, 'Canon' wanted to beat 'Xerox' (Hitt et al., 1995, Hamel and Prahalad, 1989). These expressions represent the strategic intent of Komatsu and Canon (Hamel and Prahalad, 1989). Companies are expected to have active management processes which allow consistent communication and resource allocations in line with the strategic intent so as to realize the underlying objectives (Hamel and Prahalad, 1989).

Strategic intent is said to operate as a supplement to dynamic capabilities (Døving and Gooderham, 2008), while others state that strategic intent in itself is a dynamic capability (O'Reilly 111 and Tushman, 2008, O'Shannassy, 2016). It tends to focus on exploration and exploitation activities (O'Reilly 111 and Tushman, 2011) in order to make a firm ambidextrous and improve its competitive advantage. The strategic intent of exploration typically involves discovering new opportunities that have the potential to enhance a firm's performance, while strategic intent of exploitation involves obtaining competencies and/or extending or elaborating existing capabilities and assets (Lewin et al., 1999, Koza and Lewin, 2000). This intent to be ambidextrous is nevertheless an issue that is core to dynamic capabilities (O'Reilly 111 and Tushman, 2008) due to the fact that dynamic capabilities are rooted in the ability to perform the exploration and exploitation activities simultaneously (Ancona et al., 2001, Raisch and Birkinshaw, 2008). The successful interaction of the exploration and exploitation activities 
tends to produce complex as well as enhanced capabilities that can offer an additional source of competitive advantage for firms (Colbert, 2004). These acts that lead to and/or strengthen the competitive advantage are potentially guided by the direction that is conceived by the strategic intent (Døving and Gooderham, 2008).

Scholars argue the need for a firm to have capable managers in decision-making roles, as managers with the skills to manage both exploration and exploitation are likely to better articulate their firms' strategic intent (Rui and Yip, 2008). Accordingly, extant literature asserts the significance of firms with a strong strategic intent - strategically aggressive to win competitively with utmost emphasis on winning market share (Venkatraman, 1989) - to have skilful managers (Hamel and Prahalad, 1989, Hitt et al., 1995). Along similar lines, O'Reilly 111 and Tushman (2011) allude to a potential association between strategic intent and manager's ambidexterity in firm-specific context in that they argue the need for a clear and compelling strategic intent with insights of specific micro-mechanisms/directions to guide the manager's exploration and exploitation activities. To further strengthen this argument, O'Reilly 111 and Tushman (2011) also explain how the use of managers ambidextrous skills at IBM Network Technologies assisted in exploiting existing chipset lines while carrying out exploration for building fundamentally new chips, which appears to have been performed as part of their firm's intent. These lines of arguments clearly support an inherent relationship between the strategic intent and managers' ambidexterity. Accordingly, we forward the following hypothesis:

\section{H1: Strategic intent is positively associated to managerial ambidexterity.}

Strategic intent is also said to be a key antecedent for firms that aim to engage in strategic alliances (Koza and Lewin, 1998, Yamakawa et al., 2011) such as coopetition (Luo, 2007a). It operates as a dynamic capability for firms in justifying the use of ambidexterity, i.e., the use of exploration and exploitation acts (O'Reilly 111 and Tushman, 2008, O'Shannassy, 2016). Besides, it is said to intellectually guide firms on the importance of carrying out acts necessary to make their ambidexterity a success (O'Reilly 111 and Tushman, 2011). Accordingly, strategic intent could be considered to be effective in negotiating ambidexterity and ambidextrous relationships. Luo (2007a) and Luo and Rui (2009) add that it is the strategic intent of a coopetitor that leads to coopetition at various levels including the interfirm level. Nonetheless, strategic intent being a disruptive force, encourages firms to engage in relationships with competitors in fundamentally different or even disruptive ways to create new forms of value (Charitou and Markides, 2003, Yami et al., 2010). Additionally, scholars posit that strategic intent guides to define not only the objectives for firms, but also the direction to 
achieve those objectives (Hamel and Prahalad, 1989, Johnson and Sohi, 2001). These objectives tend to include engaging in ambidextrous/paradoxical alliances to explore and exploit the resources, capabilities, and opportunities (Koza and Lewin, 1998, Yamakawa et al., 2011). Accordingly, Haugstetter and Cahoon (2010) mention that the ability to appreciate paradoxical activities and strategize them effectively is anchored by a firm's strategic intent. These arguments lead to the following hypothesis.

\section{H2: Strategic intent is positively associated to coopetition}

\section{Manager's ambidexterity}

Ambidextrous managers are highly motivated individuals who can deal with a wide variety of different as well as opposing activities (Adler et al., 1999, Mom et al., 2015) that include exploring and exploiting activities/opportunities (Mom et al., 2007, Mom et al., 2009). The dynamic capabilities view posits that in order to pursue ambidexterity, firms require their managers to accomplish ambidextrous tasks (O'Reilly 111 and Tushman, 2008). This involves managers dealing with trade-offs between simultaneous exploration and exploitation (O'Reilly 111 and Tushman, 2011) besides being able to perform complex routines of integration and differentiation of tasks. The principle of exploration activities is to broaden managers' existing knowledge base (Levinthal and March, 1993, Mom et al., 2007). These activities include new organizational norms, structures, routines, learning, systems, and adaptability, among others (Zollo and Winter, 2002, Mom et al., 2007). Alternatively, exploitation activities deepen the managers' existing knowledge base. These include (1) applying, improving, and lengthening existing competencies, products and processes, and technologies (March, 1991), and (2) refining their existing knowledge base (Levinthal and March, 1993, Mom et al., 2007, Mom et al., 2009).

Coopetition as a paradoxical relationship has been debated from the perspectives of exploration and exploitation (Padula and Dagnino, 2007, Bouncken and Kraus, 2013, Bouncken and Fredrich, 2016, Strese et al., 2016, Yousef et al., 2019) so as to illustrate the ambidexterity involved in it. While the cooperation dimension of coopetition is associated to the exploration phase, the exploitation phase is attributed to the competition dimension (Gnyawali et al., 2008, Yami and Nemeh, 2014, Yousef et al., 2019). Managers' ability to deal with exploration and exploitation potentially rationalises and strengthens a firm's willingness to pursue paradoxical relationships such as coopetition. Accordingly, extant coopetition literature debates the importance of ambidextrous managers for firms (Bengtsson et al., 2016b, Yami et al., 2010, Raza-Ullah et al., 2014, Strese et al., 2016, Bengtsson et al., 2018, Lundgren- 
Henriksson and Kock, 2016) that aim to pursue coopetition. Managers role in the development of capabilities to manage various functional paradoxical activities such as creating and appropriating value (Bengtsson and Johansson, 2014, Dagnino and Rocco, 2009, Fernandez and Chiambaretto, 2016), balancing resource sharing and resource protection (Bengtsson et al., 2016b), integrating and coordinating the contradictory demands (Eisenhardt et al., 2010), and managing paradoxical tensions (Bengtsson et al., 2016b, Raza-Ullah, 2018) are well discussed within coopetition literature. Although these studies postulate potential relationships between ambidextrous managers and ambidextrous activities associated to coopetition, it falls short of explaining not only the nature of manager skillsets but also their direct relationship with coopetition itself. However, given the potential links posited between ambidextrous managers and various paradoxical activities associated to coopetition in extant literature, this study argues that the presence of ambidextrous managers likely leads to coopetition as well. These arguments lead to the following hypothesis;

\section{H3: Manager's ambidexterity is positively associated to coopetition}

\section{The role of knowledge sharing}

Among the motives for firms to engage in strategic alliances (Glaister and Buckley, 1996, Simonin, 2004), knowledge sharing/transfers and subsequent learning has been emphasized to be crucial (Dyer and Singh, 1998, Simonin, 2004, Bouncken and Kraus, 2013, Devarakonda and Reuer, 2018). Knowledge typically contains information related to products, markets, product/service development efforts, planning functions, and intelligence related to firms strategy (Nelson, 1982, Sher and Lee, 2004, Devarakonda and Reuer, 2018). Firms in a strategic relationship hope to learn and acquire skills, technologies, and knowledge from each other through the sharing of varied knowledge which is otherwise not available outside that relationship (Lei, 1993). Given the value that knowledge adds, it is essential for firms that aim to engage in relationships to be able to share knowledge (Inkpen and Beamish, 1997, Soekijad and Andriessen, 2003) as that strongly motivates firms to engage in strategic relationships and to learn from such relationships (Soekijad and Andriessen, 2003, Bouncken and Kraus, 2013, Bouncken and Fredrich, 2016).

As a dynamic capability strategic intent seeks to perform exploration and exploitation of opportunities/activities (O'Reilly 111 and Tushman, 2008). These exploration and exploitation activities may require necessary knowledge flows to support the firm's intent and to align it with that of the partner (Norman, 2004). Alliance wide knowledge routines can assist to formulate a clear strategic intent with the specificities of the areas of exploration and 
exploitation that a firm aims to pursue in their strategic relationships. For instance, the intent to exploit growth opportunities and to adapt product markets can be better formulated by integrating a firm's existing knowledge with new knowledge gained externally (Bierly et al., 2009). Similarly, the intent of exploring new opportunities along with the partner and to rapidly generate innovative products can be better planned by integrating both the firms' knowledge (Zahra et al., 2000, Bierly et al., 2009, Bouncken and Kraus, 2013). However, pursuing the contradictory exploration and exploitation activities simultaneously could make the trade-off of ambidexterity challenging for firms (Gibson and Birkinshaw, 2004), due to the potential tensions such as trade-offs between pursuing one activity over the other (Gibson and Birkinshaw, 2004, Simsek et al., 2009). With the knowledge routines in place, firm's managers, as knowledge brokers, can differentiate the simultaneous activities (Chiambaretto et al., 2019), and deal with the trade-offs in relationships as per the firm's intent. Accordingly, scholars argue that when strategic intent is complemented by knowledge flows, managers can think and act ambidextrously for their firm to attain exploration and exploitation objectives simultaneously (He and Wong, 2004, Gibson and Birkinshaw, 2004), with better coordination and strategic control (Veliyath, 1992, Bodwell and Chermack, 2010, O'Reilly 111 and Tushman, 2011). Given that knowledge flows can strengthen the communication, coordination, and decision making, both within and across the organizations (Fan and Ku, 2010, Lawson et al., 2009), it can also ensure a clear-cut communication about strategic initiatives and processes that form the strategic intent, and guide the decision makers/managers and other stakeholders in their efforts to realise the strategic intent (Haugstetter and Cahoon, 2010). Consequently, we argue that the strategic intent complemented by knowledge flows enable the managers to deliver the objectives of the intent. Therefore:

H4: Knowledge sharing positively moderates the relationship between firm's strategic intent and its managers' ambidexterity

The dynamic capabilities perspective emphasizes upon the need for knowledge and information as necessary requirements to develop competitive advantage in relational settings (Easterby-Smith and Prieto, 2008, Niesten and Jolink, 2015). Knowledge resources allow reconfiguration of processes inherent to dynamic capabilities and assist to develop the future paths/directions for firms (Teece, 2007). Similarly, activities that are central to a firm's strategic intent, a dynamic capability, represent strategic behaviours of the firms (Hamel and Prahalad, 1989, Simsek et al., 2017), which generally seek resource requirements (Simsek et al., 2017) such as knowledge. This knowledge requirement is attributed to the firm's need for 
an accurate assessment of costs and benefits of entering into a strategic alliance. Firms expect to have a comprehensive understanding of both the strategic intent of the firms as well as knowledge over, for instance, the technological changes, stock of resources, and skills that contribute to competitive advantage (Soekijad and Andriessen, 2003). These technical knowledge and skills, and information sharing, are important parameters for the firms to be able to communicate in a transparent and receptive manner in relationships (Hamel, 1991).

Among others, the strategic objectives derived by the strategic intent tend to include entering new markets, learning and acquiring new knowledge for expanding knowledge and capabilities, and building new resource base (Rui and Yip, 2008), seeking technological advancements (Gnyawali and Park, 2011), and developing innovation (Ritala and HurmelinnaLaukkanen, 2013). Realising these strategic objectives without the knowledge sharing routines is rather challenging. Accordingly, Ritala and Hurmelinna-Laukkanen (2013) mention that engaging in coopetition without knowledge sharing is useless for firms. Extant literature also showcases the complementary role of knowledge in driving a firm's strategic intent to pursue paradoxical activities in strategic alliances (Grant and Baden-Fuller, 2004, Bouncken and Kraus, 2013, Bacon et al., 2019), building new business models (Velu, 2016, Ritala et al., 2014), and improving competitive advantage (Gnyawali et al., 2006, Bengtsson and RazaUllah, 2016). Accordingly, the study posits that knowledge sharing could play a complementary role in the relationship between strategic intent and coopetition relationship. Therefore;

H5: Knowledge sharing positively moderates the effect of a firm's strategic intent on coopetition

\section{Knowledge sharing and manager's ambidexterity as moderated mediators between strategic intent and coopetition}

The strategic intent of a firm to achieve specific objectives depends on the fit between the firm's intent at the beginning of an alliance and subsequent adoption of necessary channels (Nielsen, 2010). The idea of adopting necessary channels to pursue coopetition (what a firm wants to do) as per the intent (what a firm knows) draws similarities with the 'knowing-doing' concept forwarded by Pfeffer and Sutton (2000). Firms tend to experience potential barriers, such as communication gaps, between what a firm knows and how the firm does what it knows, thereby increasing the knowing-doing gap (Haamann and Basten, 2019). Therefore, there is a necessity for the channels to be setup in place to bridge the potential gaps. For instance, if one firm in an alliance acquires knowledge externally it has to share it with the partners in order to interlink the new knowledge to their regular routines and reduce the knowing-doing gap 
(Mahnke et al., 2005, Demeter et al., 2016). Subsequently, Pfeffer and Sutton (2000) emphasize upon two important factors - firms' managers and the knowledge, to be potential channels to reduce the knowing-doing gap. Pfeffer and Sutton (2000) refer to firm-specific cases of British Petroleum and Barclays to illustrate how these intervening channels helped each firm to reduce the knowing-doing gap.

The dynamic capabilities literature posits that ambidexterity as a dynamic capability rests on the ability of leaders/managers to not only articulate their firm's strategic intent that justifies the exploration and exploitation activities but also manage the inherent processes associated to different organizational architectures (O'Reilly 111 and Tushman, 2011), such as paradoxical relationships. In accordance, scholars argue that performing ambidextrous acts such as exploration and exploitation (or cooperation and competition) as per their firms' intent (Koza and Lewin, 1998, Yamakawa et al., 2011) requires their managerial team to articulate the strategic intent that justifies being in the ambidextrous relationship (Rotemberg and Saloner, 2000, O'Reilly 111 and Tushman, 2008). However, in order for managers to perform these ambidextrous acts in relationships, it is important that managers comprehend the intent of not only the focal firm but also that of the partner. Accordingly, Spekman et al. (1996) maintain that the managers must ensure the strategic intent of their firm is tied to the strategic alliance (objectives). This aligning of the intents is plausible with the implementation of knowledge sharing routines. With the knowledge complementing the strategic intent, a reconceived strategic intent can better guide the managers to deal with the ambidexterity activities involved in coopetition. This is due to the fact that the sharing of information and knowledge allows reducing the possible overlapping of activities such as product lines or target markets (Jorde and Teece, 1989, Luo, 2007a), and essentially the intents of partners. Therefore, the study posits knowledge as a complement for strategic intent, and ambidextrous managers as a transmitter/intervening variable in the relationship between strategic intent and coopetition. Accordingly, we forward the following hypothesis for formal testing:

H6: Manager's ambidexterity mediates the relationship between strategic intent and coopetition in that knowledge sharing simultaneously moderates the effect between strategic intent and managerial ambidexterity.

\section{Research methodology}

\section{Data collection}

The constructs identified for this study include firm-level as well as relational-level variables which represent the strategic aspects of a focal firm and assist the firm to pursue a relationship with partner firms, thus, eventually investigating a dyadic relationship (Chen and Paulraj, 
2004). Therefore, the unit of analysis is the 'dyad'. We collected data from one-side of the dyad. A mix of individuals that hold strategic as well as operational positions in organizations would be more relevant to respond to the variables investigated in this study. Accordingly, we sought responses to the survey questionnaires from top ranking managers who were knowledgeable about the coopetitive relationships of the responding firms.

A structured web-based questionnaire was employed for data collection. We utilized 'Qualtrics' software tool to build the survey by embedding all our survey questions into a shareable web-link. The survey instrument was created following extensive literature review and the sources of the survey questions are clearly explained in the measures section. The online questionnaire was self-administered for efficiency and to accommodate budget constraints for data collection. This also helps to gather a significant amount of information over a short period of time (Statsenko and Corral de Zubielqui, 2020). 'Qualtrics' software tools and their panel data are widely being utilized for data collection across the research functions (Abbey and Meloy, 2017, Statsenko and Corral de Zubielqui, 2020, Hartmann et al., 2020). We accessed and utilized the strength of Qualtrics' robust panel data to approach the qualified respondents. Later, the collected data was imported to SPSS format files for further analysis.

The target sample encompasses firms from across the North America, UK, Ireland, and Netherlands. These firms engage sectors such as automotive/automobile, consumer electronics, engineering, information and communication technologies (ICT), machinery, pharmaceuticals, and research and development (R\&D). These sectors are categorised as Hi-tech as well as knowledge intensive by the Eurostat (Eurostat, 2018), a directorate-general of the European commission which offers statistical information to the European Union's institutions. These sectors are chosen as their significance was being emphasised by scholars in coopetition research (Luo, 2007a, Ritala and Hurmelinna-Laukkanen, 2009, Dagnino and Rocco, 2009, Gnyawali and Park, 2011, Ritala and Hurmelinna-Laukkanen, 2013, Raza-Ullah et al., 2014, Wu, 2014, Chiambaretto et al., 2019). These studies suggest that coopetition is more suitable for firms that operate in knowledge intensive and technology driven sectors. The endlessly evolving standards and complex nature of technologies are obliging collaboration between rival firms (Luo, 2007a, Raza-Ullah et al., 2014). To ensure that our survey is responded to by the intended group of individuals, a screening question was placed right at the start of the survey "Does your firm cooperate and compete at the same time with a competitor firm or a firm that has similar product/service offering and similar target market" (representing cooperation and competition in the same relationship). Individuals that answered 'Yes' to the screening question 
were requested to continue with the survey keeping that competitor partner in mind, while those that answered 'No' were aborted from the survey with a thank you note. From 1500 on-line surveys sent, 355 responses were received which resulted in a response rate of $23.67 \%$. Due to inadequate information, 42 responses were discarded and that lead to an effective response rate of $20.87 \%$ (313/1500). Over $71.6 \%$ of respondents held positions such as CEOs/COOs, Alliance-directors, and top-level managers in their respective organisations. The respondents mostly worked for medium to large scale firms with $41.9 \%$ working for firms that each has an employee size of 251-1000 and 24.3\% working for firms where each has over 1001 employees. Nearly $70.3 \%$ of firms registered over EUR 50 million revenues in the previous financial year. We evaluated non-response bias by testing plausible differences between sample means of demographic variables such as employee size of focal and partner firms, and the firm age. A new variable was created to represent two independent groups based on early responses and late responses. The responses received during the first 3 weeks (until the $7^{\text {th }}$ of May 2018) were separated into group 1 while the later responses (from the $8^{\text {th }}$ of May 2018 until end of June 2018) were separated into group 2. Using the SPSS, a non-parametric two independent sample test was performed on the variables - focal firm employee size, partner firm employee size, and the firm age. The results yielded no statistically (at 95\% confidence level) significant differences between the two groups. Therefore, nonresponse bias does not appear to be a concern.

Given the fact that the study collected data from a single respondent within each sample firm regarding the variables of interest, we conducted specific tests to address concerns related to common method bias. The study conducted a confirmatory factor analysis to address common method bias related concerns (Sea-Jin et al., 2010, Roldán Bravo et al., 2018). Specifically, we ran two models - one with a single-factor and another with the factors presented in the theoretical framework. The model fit for the single factor model (Comparative fit index $[\mathrm{CFI}]=0.811$, Tucker-Lewis index $[\mathrm{TLI}]=0.789$, Incremental fit index $[\mathrm{IFI}]=0.812$, Root mean square error of approximation $[\mathrm{RMSEA}]=0.106$, normed $\chi 2[\mathrm{NC}]=4.514$ ) was much inferior to our measurement model $(\mathrm{CFI}=0.962, \mathrm{TLI}=0.953, \mathrm{IFI}=0.962, \mathrm{RMSEA}=$ 0.050 , normed $\left.\chi^{2}[\mathrm{NC}]=1.784\right)$ signifying that the common method bias is not a concern.

\section{Measures}

A 7-point Likert scale with endpoints of "strongly disagree" to "strongly agree" is used to measure the indicators used in the survey. The details of all indicators are provided in the Appendix. 
Independent variable: 'Strategic intent' is operationalized by four items adapted from Johnson and Sohi (2001) which they built following the original work of Hamel and Prahalad (1989).

Mediator variable: Measures for manager exploration and manager exploitation are adapted from Mom et al. (2007) to build the 'manager ambidexterity' construct utilising the factor method/multiplicative approach following the same authors from where the items are adapted (Mom et al., 2007). The factor or multiplicative approach was also followed in the other studies (Mom et al., 2009) to measure manager ambidexterity. These studies argue that the multiplicative approach is the most suitable approach to measure manager ambidexterity due to it being a factor that explicitly takes the ambidextrous behaviour of individuals/managers into consideration, citing the recommendation of Gibson and Birkinshaw (2004).

Moderator variable: Three items scale from Wang et al. (2008) is adapted to operationalise 'knowledge sharing'.

Dependent variable: We operationalized "Coopetition" by multiplying the cooperation and competition constructs following the "multiplicative or the product/interaction method" approach implemented in previous coopetition studies (Luo et al., 2006, Bengtsson et al., 2016b, Bendig et al., 2018). The variable "cooperation" is operationalised by five items adapted from Cannon and Perreault (1999), and "competition" is measured by a four items scale adapted from Tsai (2002) and Zhang et al. (2010). The multiplicative method is interpreted to be ideal as it represents the simultaneity of both the constructs (He and Wong, 2004, Chandrasekaran et al., 2012), i.e., simultaneous cooperation and competition.

Control variables: We control for relationship length because the firms may have an incentive gained from the relationship that could be used to influence and control over time (Luo, 2005, Morris et al., 2007, Afuah, 2000, Ho and Ganesan, 2013). The scale of a firm's operations and the amount of access it has to resources are dependent on the size of the firm (Dröge et al., 2003). Also, rivalry gets intense between firms that are relatively stronger in size (Bengtsson and Kock, 1999). Thus, we controlled for firm size as well as partner firm size. We used number of employees as a measure of firm size. We also controlled for common suppliers between alliance firms as that may influence the decision on relationship (Vachon and Klassen, 2006). Further, intensity of collaboration between competitors was also included to control for various alliance activities. Three items - amount of collaboration in $R \& D$, amount of new product development, and amount of technology development (Ritala and Hurmelinna-Laukkanen, 2013, Luo et al., 2007) were measured on a scale of 1 to 7 with endpoints of "very low" to "very high". Firm age (Years from inception) is also controlled as it could be a source of 
resource heterogeneity such as slack resources and a work force that can formulate sophisticated arrangement with partner firms (Niederkofler, 1991, Reuer et al., 2006). Besides, firm age could also influence the outcomes using its industry establishment (Ritala and Hurmelinna-Laukkanen, 2013, Lechner et al., 2016).

\section{Instrument development}

We ensured content validity of the survey instrument by grounding it in extant literature. Additionally, before the data collection took place, we pre-tested the instrument with 19 experts (15 executives and 4 academics); their opinions were sought on structure, readability, ambiguity, and completeness of the instrument (Dillman, 2007). Based on the feedback received, we made minor changes to the instrument before the survey launch. As specified previously, multi-item scales were utilised to measure all theoretical constructs. Normality and outliers for the measurement instrument was tested by using the plots of residuals and statistics of skewness and kurtosis. Multivariate outliers were tested based on Mahalanobis distances of predicted variables. The values of skewness and kurtosis were found to be within the limits of 2 and 7 (Curran et al., 1996). Additionally, the respective plots of skewness and kurtosis did not show any worrisome deviations.

Both the exploratory factor analysis (EFA) and confirmatory factor analysis (CFA) were conducted to establish construct validity and unidimensionality. The results of this analysis are presented in the Appendix. While conducting EFA, most of the items loaded onto their respective constructs. The eigenvalues for the constructs were above 1.0; the percent of variation was 59.80 and the factor loadings were also above 0.40 (Hair et al., 1998). The fit indices for the CFA model $(\mathrm{CFI}=0.962$, $\mathrm{TLI}=0.953$, IFI $=0.962, \mathrm{RMSEA}=0.050, \mathrm{SRMR}=$ 0.0421 , and normed $\left.\chi^{2}[\mathrm{NC}]=1.784\right)$ suggest adequate fit (Kline, 2005). Overall, these results clearly indicate that the proposed measurement model fits the data well, thereby establishing the unidimensionality of the measurement instrument.

Results establish the discriminant validity of the constructs since the squared correlations between all combinations of latent constructs is less than the average variance extracted (AVE) estimates of the respective constructs (Fornell and Larcker, 1981). The correlations values are provided in Table 1 and the AVE values are shown in the Appendix. Reliability of the constructs was established using internal consistency method via Cronbach's alpha (Nunnally, 1978). All constructs showed Cronbach's alpha value of greater than 0.70 (see Appendix). Alternatively, composite reliability (CR) values showed that all constructs had a CR value of greater than 0.70 (see Appendix) (Bagozzi and Yi, 1988). Moreover, AVE values 
for all constructs were not less than 0.50. Overall, the results indicate that the theoretical constructs are reliable, valid and unidimensional. During the instrument development process, we deleted some indicators as they did not meet the psychometric requirements; the deleted items are shown in the Appendix.

$$
\text { -- Insert Table } 1 \text { here -- }
$$

\section{Results of analysis}

Simple regression was performed to test the Hypotheses H1, H2, and H3. Table 2 presents these results. For H1, the prediction was that a coopetitor's strategic intent will be positively associated to its manager's ambidexterity. The results do not find support for the Hypothesis as the results indicate that strategic intent is negatively associated $(\beta=-0.195, \mathrm{p}<0.01)$ to ambidexterity. For $\mathrm{H} 2$, the prediction was that the effect of strategic intent on coopetition is positive. The results do not find support for the hypothesis as the beta value indicate that the effect of strategic intent on coopetition is insignificant $(\beta=0.036, p<0.463)$. In the case of hypothesis $\mathrm{H} 3$, the prediction was that the manager's ambidexterity is positively associated to coopetition. The results provide support for this Hypothesis, in that manager's ambidexterity on coopetition $(\beta=0.611, \mathrm{p}<0.0001)$ is found to be positive and significant.

\section{-- Insert Table 2 here --}

To test Hypothesis H4, we utilized the model 1 of PROCESS macro designed by Hayes (2018) for SPSS. For Hypothesis H4, the prediction was that 'knowledge sharing' moderates the relationship between firm's strategic intent and its manager's ambidexterity. Table 3 presents these results. The results find support for this hypothesis in that results indicate that the cross-product terms between 'Strategic intent and knowledge sharing' $(\beta=0.756, t=$ $18.368, \mathrm{p}<0.0001)$ on manager's ambidexterity is significant and positive.

\section{-- Insert Table 3 here --}

The SPSS macro PROCESS model 1 was utilised to test the last Hypothesis H5. The prediction was that 'knowledge sharing' positively moderates the relationship between firm's strategic intent and coopetition. Table 4 presents these results. The results support the hypothesis in that they indicate that the cross-product terms between 'Strategic intent and knowledge sharing' $(\beta=0.601, \mathrm{t}=12.430, \mathrm{p}<0.0001)$ on coopetition is significant and positive. 
Hypothesis H6 was tested utilising the model 7 of macro PROCESS for SPSS. The prediction was that manager's ambidexterity mediates between strategic intent and coopetition when knowledge simultaneously moderates between strategic intent and ambidexterity. Table 5 presents these results. The results find support for this hypothesis in which the values indicate that the ambidexterity positively mediates $(\beta=0.594, \mathrm{t}=12.937, \mathrm{p}<0.000)$ between strategic intent and ambidexterity when knowledge sharing routines are simultaneously in place between intent and ambidexterity.

\section{-- Insert Table 5 here --}

\section{Discussion}

The study makes several important contributions to both coopetition theory as well as practice. In particular, the results offer empirical evidence on the significance of strategic intent in enabling coopetition. More importantly, it showcases the importance of the intervening effect of 'ambidextrous managers' and the interaction effect of 'knowledge sharing' to facilitate the effect of strategic intent on coopetition. Figure 2 exhibits these results.

$$
\text { -- Insert Figure } 2 \text { here -- }
$$

Strategic intent-knowledge sharing-ambidextrous managers: The first objective of the study was to investigate the relationship between a firm's strategic intent and its manager's ambidexterity as well as the moderating role of knowledge sharing on this relationship. The findings suggest a negative association between intent and manager's ambidexterity. This contradicts not only our hypothesis but also the views from scholars that favour a possible association between intent and managers ambidexterity (O'Reilly 111 and Tushman, 2011, O'Shannassy, 2016, McCardle et al., 2019, Jarzabkowski et al., 2019). This contradiction can be attributed to the lack of alignment of a firm's strategic intent with that of its partner to sufficiently guide ambidextrous managers effectively. Every firm maintains a distinctive strategic intent; the choice of adopting strategies as per the intent is driven by not only the expected outcomes of the strategies, but also the manager's cognition of the surrounding environment (Koza and Lewin, 1998) which includes comprehending partner's interests/intent. Managers who operate in a coopetitive environment also tend to execute paradoxical activities with different resource combinations (Bengtsson et al., 2016a); these managers expect the direction they receive in the form of strategic intent to enhance their knowledge of those paradoxical activities so as to assist them to perform better (Mazloomi Khamseh et al., 2017). These views seem to clearly highlight the need for knowledge routines to be integrated along 
with strategic intent for managers to better comprehend the overarching relational environment. Without such routines, strategic intent that a firm pursues (without grasping relational understanding and partner interests) might lower the ambidextrous managers' ability to execute the activities effectively. Therefore, it is essential that a firm's intent is reconceived with the knowledge of relational processes, planning, and information over activities; such a reconceived intent could better guide managers' activities. This is clearly reflected in the support for hypothesis H4. Additionally, this is also evident from the confidence bands presented in Figure 3. According to this conditional indirect effect plot, only at higher levels of knowledge sharing does strategic intent have a significant positive effect on manager's ambidexterity.

-- Insert Figure 3 here --

Strategic intent-knowledge sharing-coopetition: The second objective was to investigate 'strategic intent-coopetition' relationship as well as the moderating effect of knowledge sharing on this relationship. The result of insignificant direct effect could be an interesting finding given that it contradicts several notions that allude to a potential direct effect (Luo, 2007a, Yami et al., 2010, Dagnino and Rocco, 2009, Haugstetter and Cahoon, 2010). Strategic intent is meant to offer direction for firms to pursue paradoxical activities such as coopetition (Mariadoss et al., 2014, Koza and Lewin, 2000). However, a standalone strategic intent that lacks clarity over the partner's interests may undermine its ability to pursue paradoxical activities effectively. The result of the insignificant effect appears to be indicative of the fact that a standalone strategic intent might not be effective in pursuing simultaneous cooperation and competition with its partner. This can be addressed with the use of relational-knowledge flows as they could potentially assist the intent on the areas/activities of cooperation and competition (Gnyawali et al., 2016). Harrison et al. (2001) and Mazloomi Khamseh et al. (2017) share similar views in that they suggest firms require knowledge over partner competencies, market scenario, regulators, and information over activities to strengthen the case for them to pursue strategic relationships such as coopetition. Therefore, strategic intent, by itself, might not be enough to lead to coopetition unless there is a synergy in terms of strategic intent of both the firms; such a synergy can only be achieved through knowledge sharing. This line of thought reflects in the finding of hypothesis H5 which suggests that knowledge positively moderates the relationship between strategic intent and coopetition. However, this finding also highlights the fact that only at higher-levels of knowledge sharing routines can strategic intent have a significant positive effect on coopetition. The confidence 
bands presented in Figure 4 supports this conjecture. While this result further aligns with views that suggest knowledge sharing complements strategic intent while engaging in alliances (Grant and Baden-Fuller, 2004, Zhang et al., 2019), our finding explicitly focuses on coopetition and forwards that strong knowledge routines complement strategic intent.

-- Insert Figure 4 here --

Ambidextrous managers-coopetition: The third objective of the study was to investigate the relationship between managers' ambidexterity and coopetition. Our result partially matches the views forwarded by various scholars that signify the importance of ambidextrous managers to perform various ambidextrous activities including value creation / value appropriation in coopetition (Bengtsson et al., 2016b, Yami et al., 2010, Raza-Ullah et al., 2014, Strese et al., 2016, Gnyawali and Park, 2011, Bengtsson et al., 2018, Czakon et al., 2019, LundgrenHenriksson and Kock, 2016). However, these studies do not consistently address the nature of ambidextrous managers' skills. Subsequently, scholars call for future research to investigate the nature of ambidextrous managers in coopetitive relationships (Czakon et al., 2019, Felício et al., 2019). Additionally, while these studies have related managers to various paradoxical activities associated to coopetition, they neither explain the direct effects between ambidextrous managers and coopetition nor do they provide empirical validation for the theoretical discourse. Our result specifically contends that ambidextrous managers are directly associated to coopetition wherein managerial ambidexterity is operationalized as a combination of exploration and exploitation skills. Further, our study is the first to establish an empirical connection between ambidextrous managers and coopetition. We believe that this finding can also allow us to expand this association into a broader perspective so as to explain how different combinations of managers' ambidextrous skills can facilitate different types of coopetition. For instance, different combinations of exploration and exploitation skills may facilitate different types of coopetition that are driven by the firms objectives, resources, and structural conditions (Bengtsson and Kock, 2000, Bengtsson et al., 2016b, Chai et al., 2019). Scholars suggest that ambidextrous managers can not only host contradictions (Mom et al., 2009), but are also capable of identifying the type of coopetition their firms intend to pursue and can adopt appropriate strategies to manage them (Akpinar and Vincze, 2016). Nevertheless, our results empirically validate that ambidextrous managers are associated to coopetition as much as they are said to be associated to ambidextrous activities.

Strategic intent-knowledge sharing-Ambidextrous managers-coopetition: The fourth objective was to investigate the moderated mediation effects of knowledge sharing and 
ambidextrous managers on the relationship between the strategic intent and coopetition. The result from this investigation partially matches the previous views of Rotemberg and Saloner (2000) and O'Reilly 111 and Tushman (2008) that allude managers to be potential articulators/mediators between strategic intent and ambidextrous form of relationships such as coopetition. However, the key factor that has been overlooked by extant research that posited manager's mediation between intent and paradoxical relationships, is the importance of knowledge routines. Our results highlight that knowledge sharing can play a complementary role in the pursuit of coopetitive relationships. The lack of information and knowledge pertaining to the details of various relationship-wide paradoxical elements could make it difficult for managers to gain deeper insights into the successful pursuit of coopetitive relationships (Bengtsson et al., 2018). Moreover, our findings also add to the 'knowing-doing' gap concept (Pfeffer and Sutton, 2000, Haamann and Basten, 2019) within the interfirm coopetition context in that ambidextrous managers and knowledge sharing can help in reducing the 'knowing(intent)-doing(coopetition)' gap.

Managerial relevance: The results offer three important implications for managers of firms that engage in coopetition. First, the results suggest that managers should maintain strong knowledge sharing routines with their partners as such routines can complement the effect of their firm's strategic intent. The strategic intent that is complemented with knowledge will have information over alliance activities and other routines that could ensure congruence between the firm's interests with relational-level interests. This would guide the managers in effectively performing ambidextrous activities. Strategic intent with knowledge complementarity would assist managers to gain clarity over the activities where they need to explore and other areas where they would need to exploit. Alternatively, strong knowledge sharing routines would also complement their firms' strategic intent in terms of differentiating the activities where their firms need to cooperate and compete simultaneously. Second, the results emphasize the need for managers to possess ambidextrous skills of simultaneous exploration and exploitation when engaging in strategic alliances such as coopetition. Such ambidextrous skills assist the managers to not only effectively negotiate pursuing simultaneous cooperation and competition, but also potentially allows them to effectively comprehend the paradoxical activities, such as value creation vs value appropriation, associated with coopetition. Third, it is important for managers to ensure the use of both the ambidextrous skills and the knowledge sharing routines concurrently to assist their firms to pursue successful coopetition. While knowledge pertaining to alliance activities complement the strategic intent to maintain congruence/synergy with that of the partner's interest, the ambidextrous managers are likely to better comprehend such 
knowledge-complemented strategic intent that can offer renewed direction to effectively pursue paradoxical activities associated to coopetition.

\section{Conclusion, limitations, and future research direction}

As the phenomena of coopetition has been receiving increased attention from both the industry as well as academia, it is important that organizations, practitioners, and academics understand the significance of strategic intent as an antecedent for firms that aim to pursue coopetition. It is also equally important to comprehend the significance of knowledge sharing routines as they could complement the strategic intent of a firm and better guide the firm's ambidextrous managers. While addressing the significance of these variables, this study is the first to address the empirical connection between a firm's strategic intent and coopetition through the use of knowledge routines and the firm's managers' ambidextrous skills. The study demonstrates that the ambidextrous managers mediate the relationship between strategic intent and coopetition when knowledge concurrently moderates the relationship between strategic intent and ambidextrous managers. Overall, the study offers important contributions to practitioners as well as to coopetition theory.

Like many empirical studies, restraint may be exercised when it comes to generalizing the findings of the study. We acknowledge several limitations of the study. First, we have included knowledge sharing as an important complement to strategic intent. However, other relational factors such as relational investments and governance arrangements may also complement the strategic intent and the relationships outlined in the study. Future research may consider delving into these areas. Second, the study is developed from a focal firm's perspective as we collected data from the focal firm of the dyad, which is a common problem in inter-firm relationships (Robson et al., 2019) and may have certain influence on the results. Third, the study has not taken the implication of knowledge characteristics such as the depth and breadth of its complexity (Ho and Ganesan, 2013). Fourth, the study has not investigated the knowledge protection in its current scope while discussing knowledge sharing routines. Given that coopetitors are serious competitors, the opportunity for knowledge spillage is very high. Future studies may consider looking into how different knowledge protection mechanisms could simultaneously moderate the relationship between intent-knowledge sharing-managers ambidexterity-coopetition relationship. Fifth, future studies may consider investigating the moderated mediation effects of knowledge sharing, ambidextrous managers, and other relevant variables on the relationship between strategic intent and cross-functional 
coopetition. Finally, the context of hi-technology industries spanning large geography is used for the study. Therefore, the results many not entirely fit or reflect to very specific contexts.

\section{References}

ABBEY, J. D. \& MELOY, M. G. 2017. Attention by design: Using attention checks to detect inattentive respondents and improve data quality. Journal of Operations Management, 53-56, 63-70.

ADLER, P. S., GOLDOFTAS, B. \& LEVINE, D. I. 1999. Flexibility versus Efficiency? A Case Study of Model Changeovers in the Toyota Production System. Organization Science, 10, 43-68.

AFUAH, A. 2000. How much do your co-opetitors' capabilities matter in the face of technological change? Strategic management journal, 21, 387-404.

AKPINAR, M. \& VINCZE, Z. 2016. The dynamics of coopetition: A stakeholder view of the German automotive industry. Industrial Marketing Management, 57, 53-63.

ANCONA, D., GOODMAN, P., LAWRENCE, B. \& TUSHMAN, M. 2001. Time: A new research lens. Academy of Management. The Academy of Management Review, 26, 645-663.

ARIÑO, A. 2002. Measures of strategic alliance performance: an analysis of construct validity. Journal of International Business Studies, 34, 66.

BACON, E., WILLIAMS, M. D. \& DAVIES, G. 2019. Coopetition in innovation ecosystems: A comparative analysis of knowledge transfer configurations. Journal of Business Research.

BAGOZZI, R. P. \& YI, Y. 1988. On the evaluation of structural equation models. Journal of the Academy of Marketing Science, 16, 74-94.

BENDIG, D., ENKE, S., THIEME, N. \& BRETTEL, M. 2018. Performance implications of cross-functional coopetition in new product development: the mediating role of organizational learning. Industrial Marketing Management, 73, 137-153.

BENGTSSON, M. \& JOHANSSON, M. 2014. Managing coopetition to create opportunities for small firms. International Small Business Journal, 32, 401-427.

BENGTSSON, M. \& KOCK, S. 1999. Cooperation and competition in relationships between competitors in business networks. Journal of Business \& Industrial Marketing, 14, 178-194.

BENGTSSON, M. \& KOCK, S. 2000. "Coopetition" in business networks - to cooperate and compete simultaneously. Industrial Marketing Management, 29, 411-426.

BENGTSSON, M. \& KOCK, S. 2014. Coopetition-Quo vadis? Past accomplishments and future challenges. Industrial Marketing Management, 43, 180-188.

BENGTSSON, M., KOCK, S., LUNDGREN-HENRIKSSON, E.-L. \& NÄSHOLM, M. 2016a. Coopetition research in theory and practice: Growing new theoretical, empirical, and methodological domains. Industrial Marketing Management, 57, 4.

BENGTSSON, M. \& RAZA-ULLAH, T. 2016. A systematic review of research on coopetition: Toward a multilevel understanding. Industrial Marketing Management, 57, 23-39.

BENGTSSON, M., RAZA-ULLAH, T. \& SRIVASTAVA, M. K. 2018. Looking different vs thinking differently: Impact of TMT diversity on coopetition capability. Long Range Planning, 101857.

BENGTSSON, M., RAZA-ULLAH, T. \& VANYUSHYN, V. 2016b. The coopetition paradox and tension: The moderating role of coopetition capability. Industrial Marketing Management, 53, 19-30.

BIERLY, P. E., DAMANPOUR, F. \& SANTORO, M. D. 2009. The Application of External Knowledge: Organizational Conditions for Exploration and Exploitation. Journal of Management Studies, 46, 481-509.

BODWELL, W. \& CHERMACK, T. J. 2010. Organizational ambidexterity: Integrating deliberate and emergent strategy with scenario planning. Technological Forecasting \& Social Change, 77, 193-202.

BONEL, E. \& ROCCO, E. 2007. Coopeting to Survive; Surviving Coopetition. International Studies of Management \& Organization, 37, 70-96. 
BOUNCKEN, R. \& KRAUS, S. 2013. Innovation in knowledge-intensive industries: The double-edged sword of coopetition. Journal of Business Research, 66, 2060-2070.

BOUNCKEN, R. B. \& FREDRICH, V. 2016. Learning in coopetition: Alliance orientation, network size, and firm types. Journal of Business Research, 69, 1753-1758.

BOUNCKEN, R. B., FREDRICH, V. \& KRAUS, S. 2020. Configurations of firm-level value capture in coopetition. Long Range Planning, 53.

CANNON, J. P. \& PERREAULT, W. D. 1999. Buyer-seller relationships in business markets. Journal of Marketing Research, 36, 439-460.

CHAI, L., LI, J., CLAUSS, T. \& TANGPONG, C. 2019. The influences of interdependence, opportunism and technology uncertainty on interfirm coopetition. Journal of Business \& Industrial Marketing, 34, 948-964.

CHANDRASEKARAN, A., LINDERMAN, K. \& SCHROEDER, R. 2012. Antecedents to ambidexterity competency in high technology organizations. Journal of Operations Management, 30, 134151.

CHARITOU, C. \& MARKIDES, C. 2003. Responses to Disruptive Strategic Innovation. MIT Sloan Management Review, 44, 55-63A.

CHEN, I. J. \& PAULRAJ, A. 2004. Towards a theory of supply chain management: the constructs and measurements. Journal of Operations Management, 22, 119-150.

CHIAMBARETTO, P., MASSÉ, D. \& MIRC, N. 2019. "All for One and One for All?" - Knowledge broker roles in managing tensions of internal coopetition: The Ubisoft case. Research Policy, 48, 584600.

COLBERT, B. 2004. The complex resource-based view: implications for theory and practice in strategic human resource management. Academy of Management review, 29, 341-358.

CURRAN, P., WEST, S. \& FINCH, J. 1996. The Robustness of Test Statistics to Nonnormality and Specification Error in Confirmatory Factor Analysis. Psychological Methods [PsycARTICLES], 1, 16.

CZAKON, W., KLIMAS, P. \& MARIANI, M. 2019. Behavioral antecedents of coopetition: A synthesis and measurement scale. Long Range Planning, 101875.

DAGNINO, G. B. \& ROCCO, E. 2009. Coopetition Strategy: Theory, experiments and cases, Oxfordshire, Routledge.

DEMETER, K., SZÁSZ, L. \& RÁCZ, B.-G. 2016. The impact of subsidiaries' internal and external integration on operational performance. International Journal of Production Economics, 182, 73-85.

DEVARAKONDA, S. V. \& REUER, J. J. 2018. Knowledge sharing and safeguarding in R\&D collaborations: The role of steering committees in biotechnology alliances. Strategic Management Journal, 39, 1912-1934.

DILLMAN, D. A. 2007. Mail and internet surveys : the tailored design method, Hoboken, N.J., Wiley.

$D \varnothing$ VING, E. \& GOODERHAM, P. N. 2008. Dynamic capabilities as antecedents of the scope of related diversification: the case of small firm accountancy practices. Strategic Management Journal, 29, 841-857.

DOWLING, M. J., ROERING, W. D., CARLIN, B. A. \& WISNIESKI, J. 1996. Multifaceted Relationships Under Coopetition. Journal of Management Inquiry, 5, 155-167.

DRÖGE, C., CLAYCOMB, C. \& GERMAIN, R. 2003. Does Knowledge Mediate the Effect of Context on Performance? Some Initial Evidence. Decision Sciences, 34, 541-568.

DYER, J. \& SINGH, H. 1998. The relational view: cooperative strategy and sources of interorganizational competitive advantage. Academy of Management review, 23, 660-679.

EASTERBY-SMITH, M. \& PRIETO, I. M. 2008. Dynamic Capabilities and Knowledge Management: an Integrative Role for Learning? *. British Journal of Management, 19, 235-249.

EISENHARDT, K., FURR, N. \& BINGHAM, C. 2010. Microfoundations of Performance: Balancing Efficiency and Flexibility in Dynamic Environments. Organization Science, 21, 1263-1275. 
ESTRADA, I. \& DONG, J. Q. 2019. Learning from experience? Technological investments and the impact of coopetition experience on firm profitability. Long Range Planning, 101866.

ESTRADA, I., FAEMS, D. \& DE FARIA, P. 2016. Coopetition and product innovation performance: The role of internal knowledge sharing mechanisms and formal knowledge protection mechanisms. Industrial Marketing Management, 53, 56-65.

EUROSTAT 2018. Eurostat statistics explained, Glossary: High-tech (High-tech aggregation by NACE Rev.2).

FAN, Y.-W. \& KU, E. 2010. Customer focus, service process fit and customer relationship management profitability: the effect of knowledge sharing. The Service Industries Journal, 30, 203-223.

FELÍCIO, J. A., CALDEIRINHA, V. \& DUTRA, A. 2019. Ambidextrous capacity in small and medium-sized enterprises. Journal of Business Research, 101, 607-614.

FERNANDEZ, A.-S. \& CHIAMBARETTO, P. 2016. Managing tensions related to information in coopetition. Industrial Marketing Management, 53, 66-76.

FORNELL, C. \& LARCKER, D. 1981. Evaluating Structural Equation Models with Unobservable Variables and Measurement Error. Journal of Marketing Research, 18, 39.

GAST, J., GUNDOLF, K., HARMS, R. \& MATOS COLLADO, E. 2019. Knowledge management and coopetition: How do cooperating competitors balance the needs to share and protect their knowledge? Industrial Marketing Management, 77, 65-74.

GIBSON, C. \& BIRKINSHAW, J. 2004. The antecedents, consequences, and mediating role of organizational ambidexterity. Academy of Management journal, 47, 209-226.

GLAISTER, K. W. \& BUCKLEY, P. J. 1996. Strategic motives for international alliance formation. Journal of Management Studies, 33, 301-332.

GNYAWALI, D., HE, J. \& MADHAVAN, R. 2006. Impact of Co-Opetition on Firm Competitive Behavior: An Empirical Examination. Journal of Management, 32, 507-530.

GNYAWALI, D., MADHAVAN, R., HE, J. \& BENGTSSON, M. 2016. The competition-cooperation paradox in inter-firm relationships: A conceptual framework. Industrial marketing management, 53, 77.

GNYAWALI, D. \& PARK, B.-J. 2011. Co-opetition between giants: Collaboration with competitors for technological innovation. Research Policy, 40, 650-663.

GNYAWALI, D. R. \& CHARLETON, T. R. 2018. Nuances in the Interplay of Competition and Cooperation: Towards a Theory of Coopetition. Journal of Management, 44, 2511-2534.

GNYAWALI, D. R., HE, J. \& MADHAVAN, R. 2008. Co-Opetition: Promises and Challenges. 21st Century Management: A Reference Handbook. Thousand Oaks, CA: SAGE Publications.

GRANT, R. M. \& BADEN-FULLER, C. 2004. A Knowledge Accessing Theory of Strategic Alliances. Journal of Management Studies, 41, 61-84.

HAAMANN, T. \& BASTEN, D. 2019. The role of information technology in bridging the knowing-doing gap: an exploratory case study on knowledge application. Journal of Knowledge Management, 23, 705-741.

HAIR, J. F., ANDERSON, R. E., TATHAM, R. L. \& BLACK, W. C. 1998. Multivariate Data Analysis, with Readings, Englewood Cliffs, NJ, Prentice-Hall.

HAMEL, G. 1991. Competition for Competence and Inter-Partner Learning Within International Strategic Alliances. Strategic Management Journal, 12, 83-103.

HAMEL, G. \& PRAHALAD, C. 1989. Strategic Intent. Harvard Business Review, 67, 63-76.

HAMEL, G. \& PRAHALAD, C. K. 2010. Strategic Intent (Harvard Business Review Classics), Harvard Business School Publishing Corporation.

HARRISON, J. S., HITT, M. A., HOSKISSON, R. E. \& IRELAND, R. D. 2001. Resource complementarity in business combinations: Extending the logic to organizational alliances. Journal of Management, 27, 679-690.

HARTMANN, N., PLOUFFE, C. R., KOHSUWAN, P. \& COTE, J. A. 2020. Salesperson influence tactics and the buying agent purchase decision: Mediating role of buying agent trust of the salesperson 
and moderating role of buying agent regulatory orientation focus. Industrial Marketing Management.

HAUGSTETTER, H. \& CAHOON, S. 2010. Strategic intent: Guiding port authorities to their new world? Research in Transportation Economics, 27, 30-36.

HAYES, A. F. 2018. Introduction to Mediation, Moderation, and Conditional Process Analysis : a Regression-Based Approach, New York, NY, The Guilford Press.

HE, Z. L. \& WONG, P. K. 2004. Exploration vs. exploitation: An empirical test of the ambidexterity hypothesis. Organization Science, 15, 481-494.

HITT, M., TYLER, B., HARDEE, C. \& PARK, D. 1995. Understanding strategic intent in the global marketplace. The Academy of Management Executive, 9, 12.

HO, H. \& GANESAN, S. 2013. Does Knowledge Base Compatibility Help or Hurt Knowledge Sharing Between Suppliers in Coopetition? The Role of Customer Participation. Journal of Marketing, 77, 91-107.

HOFFMANN, W., LAVIE, D., REUER, J. J. \& SHIPILOV, A. 2018. The interplay of competition and cooperation. Strategic Management Journal, 39, 3033-3052.

INKPEN, A. C. \& BEAMISH, P. W. 1997. Knowledge, Bargaining Power, and the Instability of International Joint Ventures. The Academy of Management Review, 22, 177-202.

JAKOBSEN, S. 2020. Managing tension in coopetition through mutual dependence and asymmetries: A longitudinal study of a Norwegian R\&D alliance. Industrial Marketing Management, 84, 251260.

JARZABKOWSKI, P., LÊ, J. \& BALOGUN, J. 2019. The Social Practice of Coevolving Strategy and Structure to Realize Mandated Radical Change. Academy of Management Journal, 62, 850.

JOHNSON, J. L. \& SOHI, R. S. 2001. The influence of firm predispositions on interfirm relationship formation in business markets. International Journal of Research in Marketing, 18, 299-318.

JORDE, T. M. \& TEECE, D. J. 1989. Competition and Cooperation: Striking the Right Balance. California Management Review, 31, 25-37.

KHANNA, T., GULATI, R. \& NOHRIA, N. 1998. The dynamics of learning alliances: competition, cooperation, and relative scope. Strategic Management Journal, 19, 193-210.

KLINE, R. B. 2005. Principles and practice of structural equation modeling, New York, Guilford.

KOZA, M. \& LEWIN, A. 1998. The co-evolution of strategic alliances. Organization science, 9, 255-264.

KOZA, M. \& LEWIN, A. 2000. Managing partnerships and strategic alliances: raising the odds of success. European Management Journal, 18, 146-151.

LAWSON, B., PETERSEN, K. J., COUSINS, P. D. \& HANDFIELD, R. B. 2009. Knowledge Sharing in Interorganizational Product Development Teams: The Effect of Formal and Informal Socialization Mechanisms *. Journal of Product Innovation Management, 26, 156-172.

LECHNER, C., SOPPE, B. \& DOWLING, M. 2016. Vertical Coopetition and the Sales Growth of Young and Small Firms. Journal of Small Business Management, 54, 67-84.

LEI, D. 1993. Offensive and defensive uses of alliances. Long Range Planning, 26, 32-41.

LEVINTHAL, D. A. \& MARCH, J. G. 1993. The myopia of learning. Strategic Management Journal, 14, 95-112.

LEWIN, A., LONG, C. \& CARROLL, T. 1999. The coevolution of new organizational forms. Organization science, 10, 535-550.

LUNDGREN-HENRIKSSON, E.-L. \& KOCK, S. 2016. Coopetition in a headwind - The interplay of sensemaking, sensegiving, and middle managerial emotional response in coopetitive strategic change development. Industrial Marketing Management, 58, 20-34.

LUO, X., RINDFLEISCH, A. \& TSE, K. 2007. Working with Rivals: The Impact of Competitor Alliances on Financial Performance. Journal of Marketing Research, 44, 73-83.

LUO, X., SLOTEGRAAF, R. J. \& PAN, X. 2006. Cross-Functional "Coopetition": The Simultaneous Role of Cooperation and Competition within Firms. Journal of Marketing, 70, 67-80.

LUO, Y. 2005. Toward coopetition within a multinational enterprise: a perspective from foreign subsidiaries. Journal of World Business, 40, 71-90. 
LUO, Y. 2007a. A coopetition perspective of global competition. Journal of World Business, 42, 129144.

LUO, Y. 2007b. From foreign investors to strategic insiders: Shifting parameters, prescriptions and paradigms for MNCs in China. Journal of World Business, 42, 14-34.

LUO, Y. \& RUI, H. 2009. An ambidexterity perspective toward multinational enterprises from emerging economies. Academy of Management perspectives, 23, 49-70.

MADHOK, A. \& TALLMAN, S. 1998. Resources, transactions and rents: Managing value through interfirm collaborative relationships. Organization Science, 9, 326-339.

MAHNKE, V., PEDERSEN, T. \& VENZIN, M. 2005. The Impact of Knowledge Management on MNC Subsidiary Performance: The Role of Absorptive Capacity. Management International Review, 45, 101-119.

MANTERE, S. \& SILLINCE, J. A. A. 2007. Strategic intent as a rhetorical device. Scandinavian Journal of Management, 23, 406-423.

MARCH, J. G. 1991. Exploration and Exploitation in Organizational Learning. Organization Science, 2, 71-87.

MARIADOSS, B. J., JOHNSON, J. L. \& MARTIN, K. D. 2014. Strategic intent and performance: The role of resource allocation decisions. Journal of Business Research, 67, 2393-2402.

MAZLOOMI KHAMSEH, H., JOLLY, D. \& MOREL, L. 2017. The effect of learning approaches on the utilization of external knowledge in strategic alliances. Industrial Marketing Management, 63, 92-104.

MCCARDLE, J., ROUSSEAU, M. \& KRUMWIEDE, D. 2019. The effects of strategic alignment and competitive priorities on operational performance: The role of cultural context. Operations Management Research, 12, 4-18.

MOM, T. J. M., FOURNÉ, S. P. L. \& JANSEN, J. J. P. 2015. Managers' Work Experience, Ambidexterity, and Performance: The Contingency Role of the Work Context. Human Resource Management, 54, s133-s153.

MOM, T. J. M., VAN DEN BOSCH, F. A. J. \& VOLBERDA, H. W. 2007. Investigating managers' exploration and exploitation activities: The influence of top-down, bottom-up, and horizontal knowledge inflows*. Journal of Management Studies, 44, 910-931.

MOM, T. J. M., VAN DEN BOSCH, F. A. J. \& VOLBERDA, H. W. 2009. Understanding Variation in Managers' Ambidexterity: Investigating Direct and Interaction Effects of Formal Structural and Personal Coordination Mechanisms. Organization Science, 20, 812-828.

MORRIS, M., KOÇAK, A. \& ÖZER, A. 2007. Coopetition as a Small Business Strategy: Implications for Performance. Journal of Small Business Strategy, 18, 35-55.

NELSON, R. R. 1982. An evolutionary theory of economic change, Cambridge, Mass. ;, Belknap Press.

NIEDERKOFLER, M. 1991. The evolution of strategic alliances: Opportunities for managerial influence. Journal of Business Venturing, 6, 237-257.

NIELSEN, B. B. 2010. Strategic fit, contractual, and procedural governance in alliances. Journal of Business Research, 63, 682-689.

NIESTEN, E. \& JOLINK, A. 2015. The Impact of Alliance Management Capabilities on Alliance Attributes and Performance: A Literature Review. International Journal of Management Reviews, 17, 69100.

NORMAN, P. M. 2004. Knowledge acquisition, knowledge loss, and satisfaction in high technology alliances. Journal of Business Research, 57, 610-619.

NUNNALLY, J. C. 1978. Psychometric Theory, New York, McGraw-Hill.

O'REILLY LLL, C. A. \& TUSHMAN, M. L. 2008. Ambidexterity as a dynamic capability: Resolving the innovator's dilemma. Research in Organizational Behavior, 28, 185-206.

O'REILLY LLL, C. A. \& TUSHMAN, M. L. 2011. Organizational Ambidexterity in Action: How Managers Explore and Exploit. California Management Review, 53, 5-22.

O'SHANNASSY, T. 2016. Strategic intent: The literature, the construct and its role in predicting organization performance. Journal of Management and Organization, 22, 583-598. 
PADULA, G. \& DAGNINO, G. B. 2007. Untangling the Rise of Coopetition: The Intrusion of Competition in a Cooperative Game Structure. International Studies of Management and Organization, 37, 32-52.

PARMIGIANI, A. \& RIVERA-SANTOS, M. 2011. Clearing a Path Through the Forest: A Meta-Review of Interorganizational Relationships. Journal of Management, 37, 1108-1136.

PFEFFER, J. \& SUTTON, R. I. 2000. The knowing-doing gap : how smart companies turn knowledge into action, Boston, Massachusetts, Harvard Business School Press.

RAISCH, S. \& BIRKINSHAW, J. 2008. Organizational Ambidexterity: Antecedents, Outcomes, and Moderators. Journal of Management, 34, 375-409.

RAZA-ULLAH, T. 2018. Experiencing the paradox of coopetition: A moderated mediation framework explaining the paradoxical tension-performance relationship. Long Range Planning, 101863.

RAZA-ULLAH, T., BENGTSSON, M. \& KOCK, S. 2014. The coopetition paradox and tension in coopetition at multiple levels. Industrial Marketing Management, 43, 189-198.

REUER, J. J., ARIÑO, A. \& MELLEWIGT, T. 2006. Entrepreneurial alliances as contractual forms. Journal of Business Venturing, 21, 306-325.

RITALA, P. 2012. Coopetition Strategy - When is it Successful? Empirical Evidence on Innovation and Market Performance. British Journal of Management, 23, 307-324.

RITALA, P., GOLNAM, A. \& WEGMANN, A. 2014. Coopetition-based business models: The case of Amazon.com. Industrial Marketing Management, 43, 236-249.

RITALA, P. \& HURMELINNA-LAUKKANEN, P. 2009. What's in it for me? Creating and appropriating value in innovation-related coopetition. Technovation, 29, 819-828.

RITALA, P. \& HURMELINNA-LAUKKANEN, P. 2013. Incremental and Radical Innovation in CoopetitionThe Role of Absorptive Capacity and Appropriability. Journal of Product Innovation Management, 30, 154-169.

ROBSON, M. J., KATSIKEAS, C. S., SCHLEGELMILCH, B. B. \& PRAMBÖCK, B. 2019. Alliance capabilities, interpartner attributes, and performance outcomes in international strategic alliances. Journal of World Business, 54, 137-153.

ROLDÁN BRAVO, M. I., RUIZ-MORENO, A. \& LLORÉNS MONTES, F. J. 2018. Examining desorptive capacity in supply chains: the role of organizational ambidexterity. International Journal of Operations \& Production Management, 38, 534-553.

ROTEMBERG, J. \& SALONER, G. 2000. Visionaries, managers, and strategic direction. The Rand Journal of Economics, 31, 693-716.

RUI, H. \& YIP, G. S. 2008. Foreign acquisitions by Chinese firms: A strategic intent perspective. Journal of World Business, 43, 213-226.

RYALS, L., J \& DAVIES, I., A 2013. Where's the strategic intent in key account relationships? Journal of Business \& Industrial Marketing, 28, 111-124.

SEA-JIN, C., ARJEN VAN, W. \& LORRAINE, E. 2010. From the Editors: Common method variance in international business research. Journal of International Business Studies, 41, 178.

SHER, P. J. \& LEE, V. C. 2004. Information technology as a facilitator for enhancing dynamic capabilities through knowledge management. Information \& Management, 41, 933-945.

SIMONIN, B. L. 2004. An empirical investigation of the process of knowledge transfer in international strategic alliances. Journal of International Business Studies, 35, 407.

SIMSEK, Z., HEAVEY, C. \& FOX, B. C. 2017. (Meta-)framing strategic entrepreneurship. Strategic Organization, 15, 504-518.

SIMSEK, Z., HEAVEY, C., VEIGA, J. F. \& SOUDER, D. 2009. A Typology for Aligning Organizational Ambidexterity's Conceptualizations, Antecedents, and Outcomes. Journal of Management Studies, 46, 864-894.

SIRMON, D., G \& LANE, P., J 2004. A model of cultural differences and international alliance performance. Journal of International Business Studies, 35, 306.

SOEKIJAD, M. \& ANDRIESSEN, E. 2003. Conditions for Knowledge Sharing in Competitive Alliances. European Management Journal, 21, 578-587. 
SPEKMAN, R. E., ISABELLA, L. A., MACAVOY, T. C. \& FORBES, T. 1996. Creating strategic alliances which endure. Long Range Planning, 29, 346-357.

STATSENKO, L. \& CORRAL DE ZUBIELQUI, G. 2020. Customer collaboration, service firms' diversification and innovation performance. Industrial Marketing Management, 85, 180-196.

STRESE, S., MEUER, M. W., FLATTEN, T. C. \& BRETTEL, M. 2016. Examining cross-functional coopetition as a driver of organizational ambidexterity. Industrial Marketing Management, 57, 40-52.

TEECE, D. 2007. Explicating dynamic capabilities: the nature and microfoundations of ( sustainable) enterprise performance. Strategic Management Journal, 28, 1319-1350.

TSAI, W. P. 2002. Social structure of "coopetition" within a multiunit organization: Coordination, competition, and intraorganizational knowledge sharing. Organization Science, 13, 179-190.

VACHON, S. \& KLASSEN, R. D. 2006. Green project partnership in the supply chain: the case of the package printing industry. Journal of Cleaner Production, 14, 661-671.

VELIYATH, R. 1992. Strategic planning: Balancing short-run performance and longer term prospects. Long Range Planning, 25, 86-97.

VELU, C. 2016. Evolutionary or revolutionary business model innovation through coopetition? The role of dominance in network markets. Industrial Marketing Management, 53, 124-135.

VENKATRAMAN, N. 1989. Strategic orientation of business enterprises - the construct, dimensionality and measurement. Management science, 35, 942-962.

WANG, Q., BRADFORD, K., XU, J. \& WEITZ, B. 2008. Creativity in buyer-seller relationships: The role of governance. International Journal of Research in Marketing, 25, 109-118.

WU, J. 2014. Cooperation with competitors and product innovation: Moderating effects of technological capability and alliances with universities. Industrial Marketing Management, 43, 199-209.

YAMAKAWA, Y., YANG, H. \& LIN, Z. 2011. Exploration versus exploitation in alliance portfolio: Performance implications of organizational, strategic, and environmental fit. Research Policy, 40, 287-296.

YAMI, S., CASTALDO, S., DAGNINO, G. B. \& LE ROY, F. 2010. Coopetition : winning strategies for the 21st century, Cheltenham, UK ;, Edward Elgar.

YAMI, S. \& NEMEH, A. 2014. Organizing coopetition for innovation: The case of wireless telecommunication sector in Europe. Industrial Marketing Management, 43, 250-260.

YOUSEF, B., RAFI-UL-SHAN, P., BASHIRI, M., HASAN, R., AMAR, H. \& KHAN, M. 2019. Exploring the role of ambidexterity and coopetition in designing resilient fashion supply chains: a multi-evidence based approach. Journal of Enterprise Information Management.

YOUSEF, B. M., PIYYA MUHAMMAD, R.-U.-S., MAHDI, B., RUAA, H., HASSAN, A. \& MUHAMMAD NAVEED, K. 2020. Exploring the role of ambidexterity and coopetition in designing resilient fashion supply chains: a multi-evidence-based approach. Journal of enterprise information management, ahead-of-print.

ZAHRA, S., IRELAND, R. \& HITT, M. 2000. International expansion by new venture firms: international diversity, mode of market entry, technological learning, and performance. Academy of Management journal, 43, 925-950.

ZHANG, H., SHU, C., JIANG, X. \& MALTER, A. J. 2010. Managing Knowledge for Innovation: The Role of Cooperation, Competition, and Alliance Nationality. Journal of International Marketing, 18, 74-94.

ZHANG, W., JIANG, Y. \& ZHANG, W. 2019. Capabilities for Collaborative Innovation of Technological Alliance: A Knowledge-Based View. IEEE Transactions on Engineering Management, 1-11.

ZOLLO, M. \& WINTER, S. 2002. Deliberate learning and the evolution of dynamic capabilities. Organization science, 13, 339-351. 


\section{Appendix}

Figure 1: Conceptual model

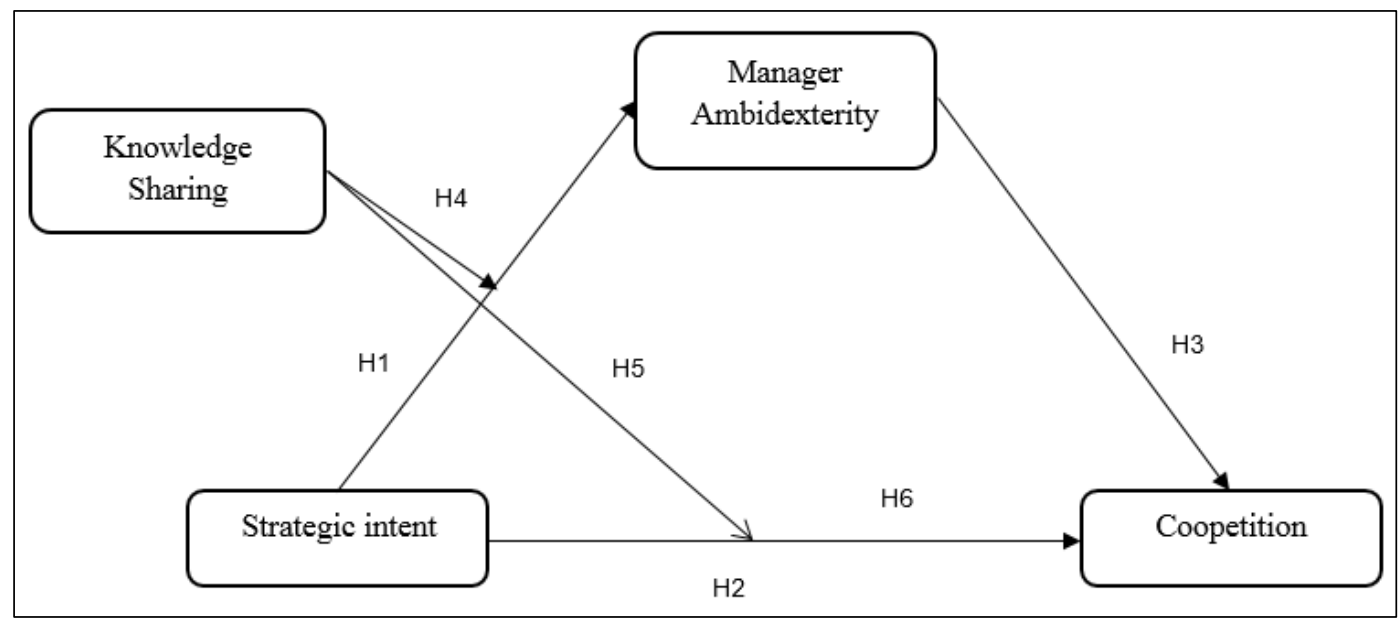

Figure 2: Results of the conceptual model

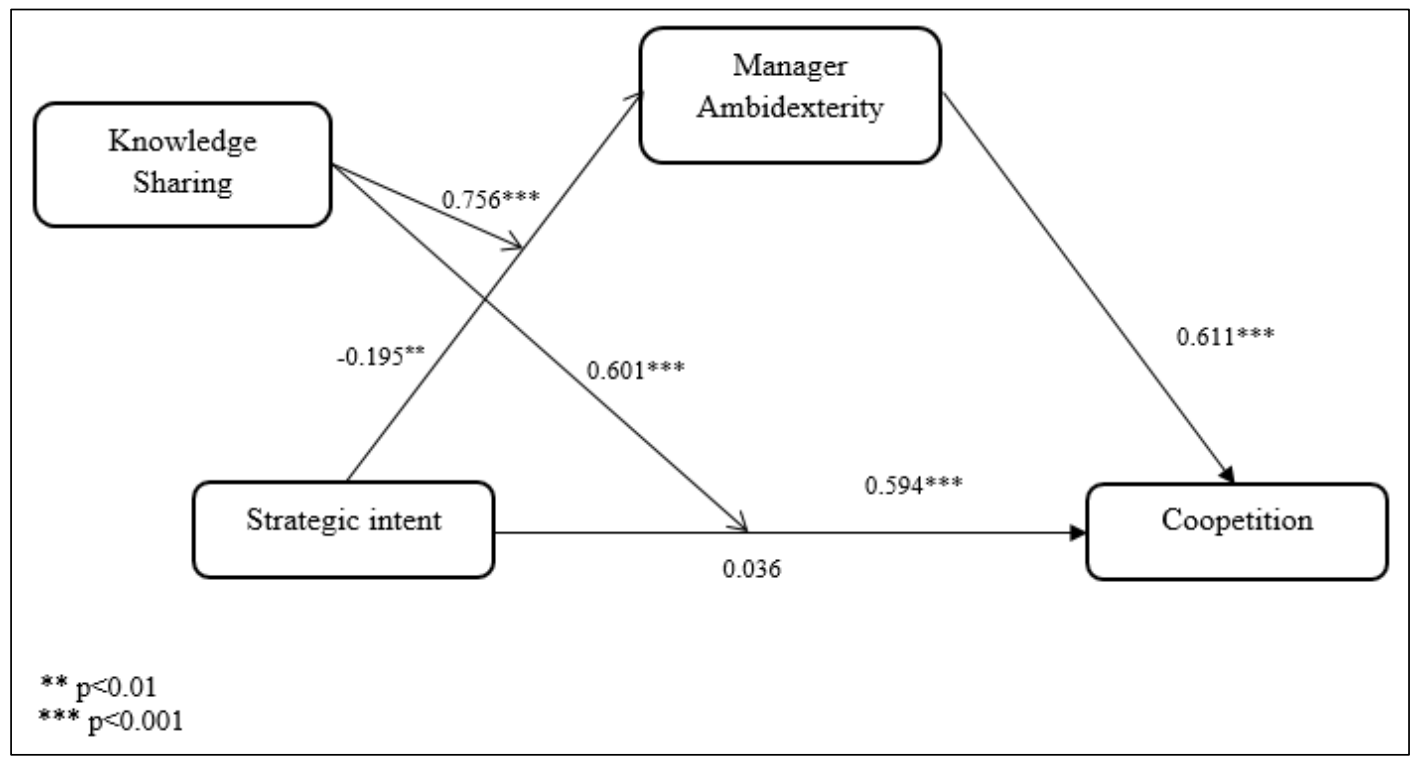


Figure 3: Conditional indirect effect of Strategic intent on Manager's ambidexterity at different levels of knowledge sharing

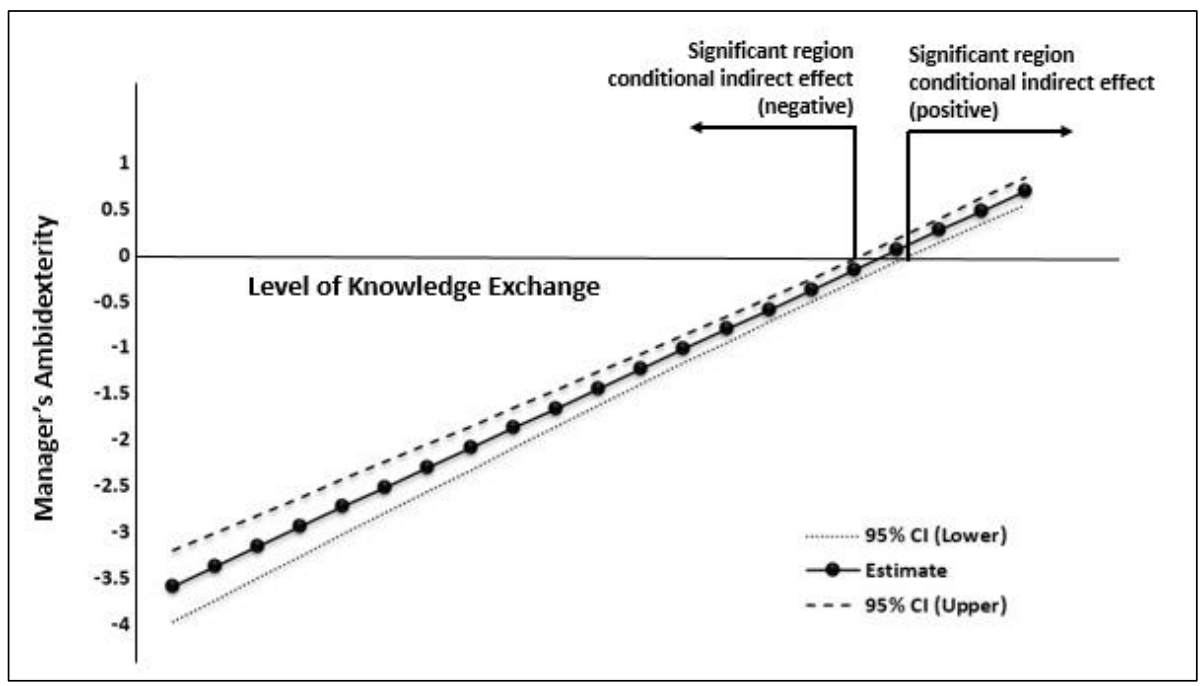

Figure 4: Conditional indirect effects of Strategic intent on Coopetition at different levels of knowledge sharing

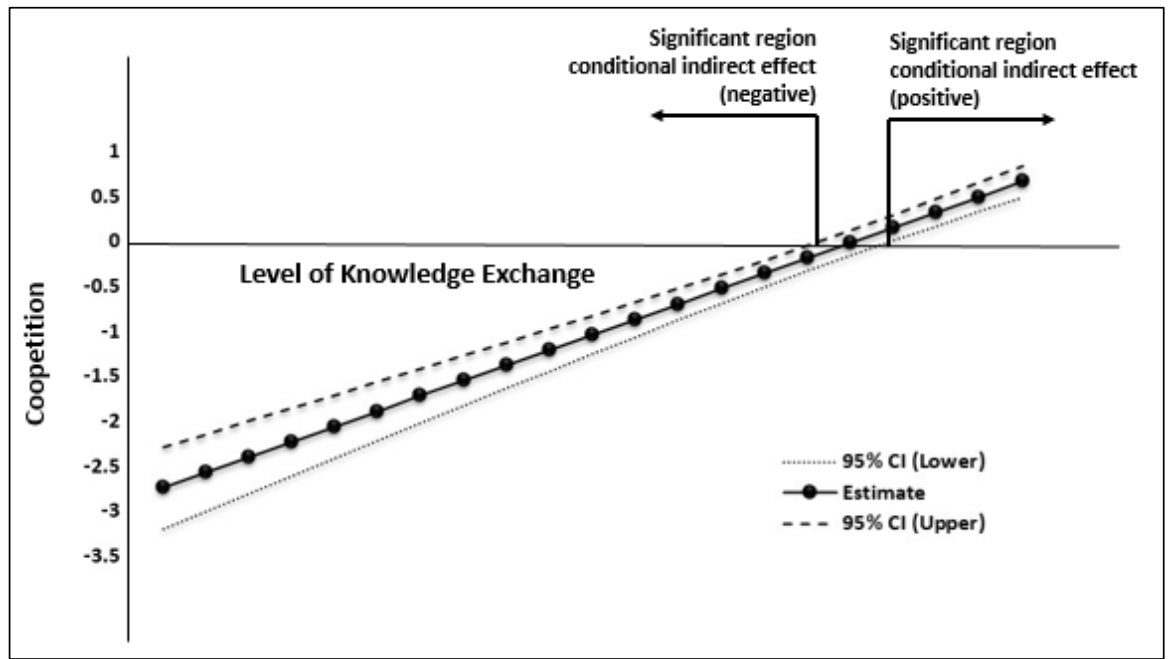

Table 1: Correlations

\begin{tabular}{|c|c|c|c|c|c|c|c|c|}
\hline Factors & Mean & SD & $\mathrm{CO}$ & CT & SI & KS & ME & MX \\
\hline $\begin{array}{l}\text { Cooperation } \\
(\mathrm{CO})\end{array}$ & 5.622 & 1.004 & 1 & & & & & \\
\hline $\begin{array}{l}\text { Competition } \\
\text { (CT) }\end{array}$ & 5.528 & 1.036 & 0.643 & 1 & & & & \\
\hline $\begin{array}{l}\text { Strategic Intent } \\
\text { (SI) }\end{array}$ & 5.282 & 1.127 & 0.499 & 0.446 & 1 & & & \\
\hline $\begin{array}{l}\text { Knowledge } \\
\text { Sharing (KS) }\end{array}$ & 5.621 & 1.048 & 0.705 & 0.568 & 0.500 & 1 & & \\
\hline
\end{tabular}




\begin{tabular}{|lccccccccc|}
\hline $\begin{array}{l}\text { Manager } \\
\text { Exploration (ME) }\end{array}$ & 5.511 & 1.034 & 0.574 & 0.472 & 0.506 & 0.637 & 1 & \\
$\begin{array}{l}\text { Manager } \\
\text { Exploitation(MX) }\end{array}$ & 5.641 & 0.951 & 0.621 & 0.557 & 0.545 & 0.640 & 0.716 & 1 \\
\hline
\end{tabular}

\section{Regression results:}

Table 2: Simple regression - Direct effects

\begin{tabular}{|c|c|c|}
\hline IV & $\begin{array}{l}\text { DV (Manager's } \\
\text { ambidexterity) }\end{array}$ & DV (Coopetition) \\
\hline \multicolumn{3}{|l|}{$\underline{\text { Control variables }}$} \\
\hline Employee strength & 0.036 & 0.009 \\
\hline Partner's employee strength & 0.028 & 0.068 \\
\hline Relationship length & 0.077 & -0.008 \\
\hline Common suppliers & -0.052 & $0.091 *$ \\
\hline Company Age & -0.089 & 0.005 \\
\hline Amount of R\&D collaboration & $-0.225 * *$ & -0.083 \\
\hline $\begin{array}{l}\text { Amount of new product } \\
\text { development }\end{array}$ & 0.040 & 0.040 \\
\hline $\begin{array}{l}\text { Amount of technology } \\
\text { development }\end{array}$ & 0.002 & -0.086 \\
\hline \multicolumn{3}{|l|}{$\underline{\text { Predictor }}$} \\
\hline Strategic intent & $-0.195 * *$ & \\
\hline Strategic intent & & 0.036 \\
\hline Manager's ambidexterity & & $0.611 * * *$ \\
\hline \multicolumn{3}{|l|}{ Model summary } \\
\hline $\mathrm{R}^{2}$ & 0.104 & 0.412 \\
\hline Adjusted $\mathrm{R}^{2}$ & 0.077 & 0.392 \\
\hline Model F-value & $3.820 * * *$ & $20.599 * * *$ \\
\hline
\end{tabular}

The regression coefficients are reported as beta values.

$\mathrm{N}=313$.

$* \mathrm{p}<0.05$

$* * \mathrm{p}<0.01$

$* * * \mathrm{p}<0.001$

Table 3: Regression results for conditional indirect effects (Strategic intent * Knowledge sharing on manager's ambidexterity)

\begin{tabular}{|lllllll|}
\hline & $\mathrm{B}$ & $\mathrm{SE}$ & $\mathrm{t}$ & $\mathrm{p}$ & $\mathrm{LLCI}$ & ULCI \\
\hline Strategic Intent $(\mathrm{SI})$ & -0.329 & 0.062 & -5.337 & 0.000 & -0.450 & -0.208 \\
& & & & & & \\
Knowledge sharing (KS) & 0.220 & 0.080 & 2.737 & 0.007 & 0.062 & 0.378 \\
SI $\times$ KS & 0.756 & 0.041 & 18.368 & 0.000 & 0.675 & 0.837 \\
& & & & & \\
Model values: $\mathrm{R}=0.772, \mathrm{R}^{2}=0.596, p=0.000$ & & & & \\
\hline
\end{tabular}

Note: $\mathrm{N}=313$. Unstandardized regression coefficients are reported. Bootstrap sample size $=5000$. LLCI $=$ lower limit confidence interval; ULCI = upper limit confidence interval. All control variables included as explained in the measures 
section, R\&D collaboration is significant. Total conditional effect at value of moderator $/$ knowledge sharing $=0.448$, Intervals (LLCI, ULCI) range $=(-1.217,-0.911)$ to $(0.310,0.585)$.

Table 4: Regression results for conditional indirect effects (Strategic intent * Knowledge sharing on Coopetition)

\begin{tabular}{|lllllll|}
\hline & $\mathrm{B}$ & $\mathrm{SE}$ & $\mathrm{t}$ & $\mathrm{p}$ & $\mathrm{LLCI}$ & ULCI \\
\hline Strategic Intent $(\mathrm{SI})$ & -0.149 & 0.073 & -2.005 & 0.041 & -0.291 & -0.006 \\
& & & & & & \\
Knowledge sharing $(\mathrm{KS})$ & 0.150 & 0.094 & 1.585 & 0.114 & -0.036 & 0.336 \\
$\mathrm{SI} \times \mathrm{KS}$ & 0.601 & 0.048 & 12.430 & 0.000 & 0.506 & 0.696 \\
& & & & & & \\
Model values: $\mathrm{R}=0.640, \mathrm{R}^{2}=0.410, p=0.000$. & & & & \\
\hline
\end{tabular}

Note: $\mathrm{N}=313$. Unstandardized regression coefficients are reported. Bootstrap sample size $=5000$. LLCI $=$ lower limit confidence interval; ULCI = upper limit confidence interval. All control variables included as explained in the measures section, R\&D collaboration is significant. Total conditional effect at values of moderator $/$ knowledge sharing $=0.469$, Intervals (LLCI, ULCI) range $=(-0.914,-0.554)$ to $(0.307,0.630)$.

Table 5: Regression results for conditional indirect effects (Strategic intent * Knowledge sharing - Manager's ambidexterity - Coopetition)

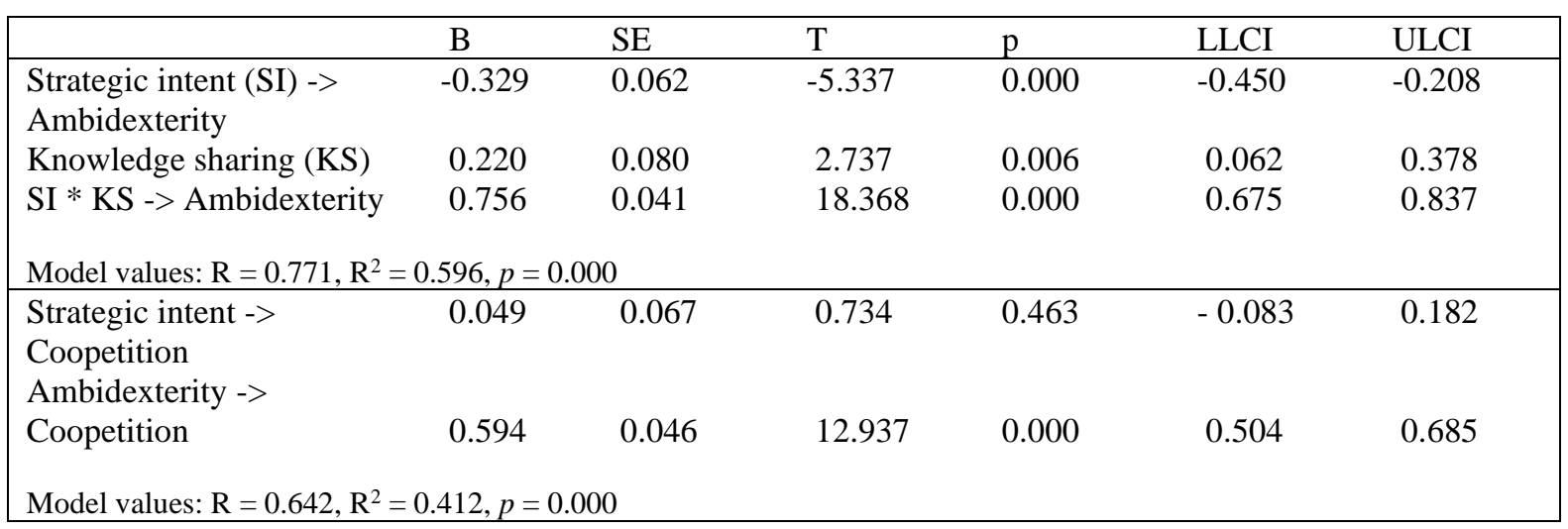

Note: $\mathrm{N}=313$. Unstandardized regression coefficients are reported. Bootstrap sample size $=5000$. LLCI $=$ lower limit confidence interval; ULCI $=$ upper limit confidence interval. All control variables included as explained in the measures section, except common suppliers none are significant. Indirect effect (SI - Ambidexterity - Coopetition) $=0.266$, Intervals (LLCI, ULCI) range $=(-0.920,-0.164)$ to $(0.056,0.482)$. Index of moderated mediation $/ \mathrm{KS}=0.450(0.119,0.636)$.

\section{Factor Analysis}

Strategic intent $(\alpha=0.857$; AVE $=0.60 ; \mathrm{CR}=0.86)$

Loadings

Is strategically aggressive?

0.734

0.802

Seeks competitive dominance?

0.822

Focuses on ambitious strategic targets and goals?

0.747

Knowledge sharing $(\alpha=0.806 ;$ AVE $=0.58 ; \mathrm{CR}=0.81)$

Both firms have set up rules for regular information sharing activities.

Both firms have established norms and procedures for sharing information.

Both firms regularly assign budgets to encourage knowledge and information sharing.

0.734

Manager Exploration $(\alpha=0.768 ; \mathrm{AVE}=0.52 ; \mathrm{CR}=0.76)$

Searching for new possibilities with respect to products/services, processes or markets*. Focusing on strong renewal of products/services or processes. 
Activities requiring quite some adaptability of you.

Activities requiring you to learn new skills or knowledge.

Manager Exploitation $(\alpha=0.836 ; \mathrm{AVE}=0.57 ; \mathrm{CR}=0.84)$

Activities of which a lot of experience has been accumulated by yourself*.

Activities which serve existing (internal) customers with existing services/products.

Activities of which it is clear to you how to conduct them.

Activities which you can properly conduct by using your present knowledge.

0.749

Activities which clearly fit into existing company policy.

Cooperation $(\alpha=0.743 ; \mathrm{AVE}=0.50 ; \mathrm{CR}=0.75)$

No matter who is at fault, problems are joint responsibilities*.

Both firms are willing to make cooperative changes.

0.726

Both firms work together to achieve a common goal

Both parties are concerned about the other's profitability.

One party will not take advantage of a strong bargaining position*.

Competition $(\alpha=0.780 ; \mathrm{AVE}=0.54 ; \mathrm{CR}=0.78)$

We have the same suppliers as our partner*.

We are in the same product market as the partner.

0.705

We have a product line very similar to the partner's.

We need the same type of knowledge related to new product or process development as the partner's. 